Abstracta Iranica Abstracta Iranica

Revue bibliographique pour le domaine irano-aryen

Volume 34-35-36 | 2017

Comptes rendus des publications de 2011-2013

\title{
S. G. Botalov, A. D. Tairov. Excavations at the Kichigino Burial Site (South Urals) in 2007: Preliminary Results
}

\section{Astrid Nunn}

\section{(2) OpenEdition \\ Journals}

Édition électronique

URL : http://journals.openedition.org/abstractairanica/41567

DOI : 10.4000/abstractairanica.41567

ISSN : 1961-960X

Éditeur :

CNRS (UMR 7528 Mondes iraniens et indiens), Éditions de l'IFRI

Référence électronique

Astrid Nunn, « S. G. Botalov, A. D. Tairov. Excavations at the Kichigino Burial Site (South Urals) in 2007: Preliminary Results », Abstracta Iranica [En ligne], Volume 34-35-36 | 2017, document 33, mis en ligne le 15 juillet 2016, consulté le 02 octobre 2020. URL : http://journals.openedition.org/abstractairanica/ 41567 ; DOI : https://doi.org/10.4000/abstractairanica.41567

Ce document a été généré automatiquement le 2 octobre 2020.

Tous droits réservés 


\title{
S. G. Botalov, A. D. Tairov.
} Excavations at the Kichigino Burial Site (South Urals) in 2007: Preliminary Results

\author{
Astrid Nunn
}

\section{RÉFÉRENCE}

S. G. Botalov, A. D. Tairov. « Excavations at the Kichigino Burial Site (South Urals) in 2007: Preliminary Results ». Ancient West \& East, vol. 10, 2011, p. 349-358.

1 Le site de Kichigino est situé dans l'Ural du sud (Russie). Ce site est composé de douze tumuli dont le diamètre varie de 14 à $35 \mathrm{~m}$. Le tumulus $\mathrm{n}^{\circ} 3$ contenait six tombes qui furent fouillées en 2007. Le centre du tumulus était occupé par une construction en bois où se trouvait une tombe, les cinq autres tombes ayant été creusées autour du centre et formant ainsi un cercle. À part la tombe 6, aucune tombe ne fut pillée. Ainsi fut révélée une richesse inouïe. Un carquois avec 200 flèches de bronze et une épée en fer de $93 \mathrm{~cm}$ se trouvaient respectivement dans les tombes masculines 1 et 2 . La plus riche des tombes féminines contenait entre autres un torque en bronze plaqué d'or et aux extrémités en forme d'animaux. Ce matériel remonte à la première moitié $d u \mathrm{IV}^{\mathrm{e}} \mathrm{s}$. av. J.-C. Les défunts devaient appartenir à la riche aristocratie des tribus nomades. 


\section{AUTEURS}

\section{ASTRID NUNN}

Université de Munich 